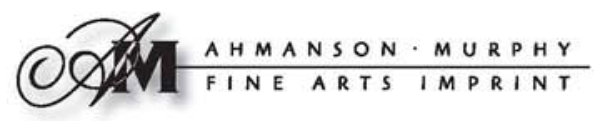

THE A H M A N O N FOU N D A T ION has endowed this imprint to honor the memory of FRAN K LIN D. MURPH Y who for half a century served arts and letters, beauty and learning, in equal measure by shaping with a brilliant devotion those institutions upon which they rely. 
Divided Rule 
The publisher gratefully acknowledges the generous support of the Ahmanson Foundation Humanities Endowment Fund of the University of California Press Foundation. 


\section{Divided Rule}

SOVEREIGNTY AND EMPIRE IN

FRENCH TUNISIA, I 88I-I938

Mary Dewhurst Lewis

届

U N I VERSITY OF CALIFORNIA PRESS

BERKELEY LOS ANGELES LONDON 
University of California Press, one of the most distinguished university presses in the United States, enriches lives around the world by advancing scholarship in the humanities, social sciences, and natural sciences. Its activities are supported by the UC Press Foundation and by philanthropic contributions from individuals and institutions. For more information, visit www.ucpress.edu.

University of California Press

Berkeley and Los Angeles, California

University of California Press, Ltd.

London, England

(C) 2014 by The Regents of the University of California

Library of Congress Cataloging-in-Publication Data

Lewis, Mary Dewhurst.

Divided rule : sovereignty and empire in French Tunisia, I88I-1938 / Mary Dewhurst Lewis.

p. $\mathrm{cm}$.

Includes bibliographical references and index.

ISBN 978-0-520-27915-5 (cloth : alk. paper)

I. Tunisia-History-French occupation, $188 \mathrm{I}-1956$. 2. Tunisia-

Politics and government-188I-1956. 3. France-Colonies-Africa,

North-History. I. Title.

$\mathrm{DT}_{2} 64 . \mathrm{L}_{35} \quad 2013$

961.104-dc23

2013018465

Manufactured in the United States of America

$\begin{array}{llllllllll}23 & 22 & 21 & 20 & \text { I9 } & \text { I8 } & \text { I7 } & \text { I6 } & \text { I5 } & \text { I4 }\end{array}$

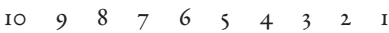

In keeping with a commitment to support environmentally responsible and sustainable printing practices, UC Press has printed this book on Natures Natural, a fiber that contains $30 \%$ post-consumer waste and meets the minimum requirements of ANSI/NISO z39.48-1992 (R 1997) (Permanence of Paper). 
For Peter 